Informatika i sistemy upravleniya. - 2016. - No. 2(48). - P. 36-47.

Dmitriev V.M. (dmitriewvm@gmail.com), Grigorieva T.E. (tanya_grig_1991@mail.ru), Panov S.A. (spytech3000@gmail.com), Istigecheva E.V. (ievne@mail.ru), Dmitriev I.V. Tomsk State University of Control Systems and Radioelectronics

\title{
FORMALISM OF PETRI NETS WITH TRANSACTS FOR BUSINESS PROCESS MODELLING
}

The article presents modeling of business processes on the basis of Petri nets with transacts and describes formalism of Petri nets with transacts in to the method of component chains. It was particularly developed "Sale" model on the example of flower shop presented on three layers: object, logical and visual for effective administrative decisions taken.

Keywords: business processes, Petri nets, transacts, modeling of business processes, method of component chains (MCC), types of business process models, multilevel computer model.

DOI: $10.22250 /$ isu.2016.48.36-47

For citation:

Dmitriev V.M., Grigorieva T.E., Panov S.A., Istigecheva E.V., Dmitriev I.V. FORMALISM OF PETRI NETS WITH TRANSACTS FOR BUSINESS PROCESS MODELLING // Informatika i sistemy upravleniya. - 2016. - No. 2(48). - P. 36-47. 